\title{
Studi Komparasi Tipologi Arsitektur Rumah Limas di Provinsi Lampung dengan Rumah Limas di Sumatera Selatan
}

\author{
Febriano Asmendo ${ }^{1}$, Shofia Islamia Ishar ${ }^{1 *}$
}

\author{
${ }^{1}$ Laboraturium Perancangan Arsitektur, Program Studi Arsitektur, Fakultas Teknik, Universitas Bandar Lampung \\ *Penulis Korespondensi: shofia.ishar@ubl.ac.id; Telp. +62 812-7154-6412
}

\begin{abstract}
Abstrak:
Arsitektur nusantara pada umumnya identik dengan suatu suku dan lokasi di mana suku tersebut tinggal. Namun, ada beberapa suku di Indonesia yang mempunyai karakter nomadik atau suka berpindah-pindah, salah satunya adalah Suku Semende dari Sumatera Selatan. Kepindahan mereka ke Provinisi Lampung turut membawa warisan budaya berupa rumah tradisional yang bernama Rumah Limas. Sehingga Sumatera Selatan yang awalnya sangat identik sebagai tempat asal Rumah Limas tidak lagi menjadi satu-satunya tempat di mana Rumah Limas bisa ditemukan. Sejak peresmian Provinsi Lampung yaitu pada tahun 1947 dan akibat dari berpisahnya Lampung dari Provinsi Sumatera Selatan, Lokasi yang menjadi tempat Suku Semende tinggal masuk ke dalam wilayah Provinsi Lampung. Hal ini menjadi cikal bakal bermukim dan menyebarnya Suku Semende di Provinsi Lampung tepatnya di Kecamatan Pulau Panggung, Kabupaten Tanggamus. Dengan adanya fenomena tersebut, maka muncul pertanyaan apakah Rumah Limas di Lampung sama dengan Rumah Limas yang ada di Sumatera Selatan. Oleh karena itu, penelitian ini akan membahas ciri khas Rumah Limas yang terdapat di daerah asalnya yaitu di Sumatera Selatan kemudian membandingkannya dengan Rumah Limas yang dibangun oleh Suku Semende di Kecamatan Pulau Panggung, Tanggamus, Provinsi Lampung. Dengan menggunakan metode komparatif, arsitektur Rumah Limas akan dibahas secara terperinci dari berbagai variabel elemen arsitekturnya seperti atap, dinding, jendela, pintu, lantai, pagar dan tangga. Terdapat empat desa di Kecamatan Pulau Panggung yang akan diteliti yaitu Desa Muara Dua, Desa Gunung Meraksa, Desa Tanjung Begelung dan Desa Gunung Megang. Rumah Limas yang ditemukan di keempat desa ini akan dianalisis persamaan dan perbedaan karakternya dengan Rumah Limas yang berada di Sumatera Selatan.
\end{abstract}

Kata Kunci: tipologi; Rumah Limas; Sumatera Selatan; Lampung

\section{Latar Belakang}

Provinsi Lampung dan Sumatera Selatan merupakan provinsi yang secara geografis saling bersebelahan. Pada tahun 1945 sampai 1947, Sumatera Selatan merupakan sub provinsi Sumatera. Lampung pada waktu itu termasuk ke dalam sub provinsi tersebut dengan nama Karesidenan Lampung (Warganegara, n.d.). Hingga pada 18 Maret 1964, Lampung resmi menjadi provinsi. Sejarah ini menyisakan cerita tentang suku asli Sumatera Selatan yang tetap tinggal di Lampung meskipun Lampung tidak lagi menjadi bagian dari Sumatera Selatan. (Pemerintah Provinsi Lampung, n.d.) Suku tersebut adalah suku Semende, suku yang selama ini dikenal sebagai suku asli Sumatera Selatan, selama puluhan tahun telah tinggal di Kecamatan Pulau Panggung, Tanggamus, Lampung.

Suku Semende di Sumatera Selatan selama ini dikenal sebagai suku yang menetap di bukit barisan di Sumatera Selatan dan dikenal sebagai suku yang suka merantau (Wijaya, n.d.). Oleh karena itu, tidak heran jika suku ini mampu beradaptasi di luar wilayah aslinya. Suku Semende yang tinggal di Kecamatan Pulau Panggung, Tanggamus, masih mewarisi tradisi leluhurnya dalam wujud seni, mereka membentuk SBS (Seni Budaya Semende) sebagai salah satu upaya untuk menjaga warisan leluhur (NN, n.d.). Selain di bidang seni, Suku Semende di Kecamatan Pulau Panggung ini juga masih menggunakan Rumah Limas yang merupakan rumah tradisional Sumatera Selatan sebagai rumah tinggalnya. Meskipun keberadaannya sudah sangat terbatas, Rumah Limas masih bisa ditemui di empat desa di Kecamatan Pulau Panggung yaitu di Desa Muara Dua, Desa Gunung Meraksa, Desa Tanjung Begelung dan Desa Gunung Megang.

Rumah Limas adalah rumah dengan karakteristik rumah panggung dan mempunyai atap limas atau piramida terpenggal. Bagi masyarakat ibukota Sumatera Selatan yaitu Palembang, Rumah Limas telah menjadi simbol peradaban masyarakat karena dianggap memiliki peran penting dalam pembentukan peradaban masyarakat (Tondi \& Iryani, 2018). Rumah Limas merupakan rumah yang dirancang dengan konsep adaptasi terhadap alam di iklim tropis. Struktur panggung dipilih karena dinilai cocok untuk menghindari kerusakan apabila terjadi banjir dan juga merupakan bentuk adaptasi jika tapak merupakan area rawa (Tondi \& Iryani, 2018).

Fenomena Rumah Limas yang berada di Tangamus akhirnya memiliki daya tarik tersendiri yaitu tentang 
bagaimana suatu suku dapat bertahan di luar wilayah aslinya dan tetap berupaya membangun rumah tradisional warisan leluhur. Sehingga muncul pertanyaan apakah Rumah Limas yang dibangun oleh Suku Semende di Kecamatan Pulau Panggung, Tanggamus sama dengan Rumah Limas yang berada di Palembang atau di Sumatera Selatan. Apa saja perubahan yang terjadi pada Rumah Limas setelah melalui proses adaptasi dengann ingkungan dan masyarakat baru di Provinsi Lampung.

Sayangnya, informasi tentang Rumah Limas di Kecamatan Pulau Panggung sangat minim. Minimnya informasi mengindikasikan bahwa kurangnya perhatian terhadap upaya melestarikan arsitektur lokal. Kondisi Rumah Limas di Kecamatan Pulau Panggung, Tanggamus juga sudah sangat memprihatinkan. Rumah Limas hanya tersisa di empat desa di kecamatan tersebut dengan kondisi yang hampir rusak. Oleh karena itu, penelitian ini akan membahas tentang karakteristik Rumah Limas yang dibangun oleh Suku Semende di Kecamatan Pulau Panggung, Tanggamus, Lampung. Dengan menggunakan metode kualitatif deskriptif, arsitektur Rumah Limas akan dibahas secara terperinci mulai dari konsep perancangan, pembagian ruang, sistem struktur, sampai ke ornamentasi bangunan.

\section{Kajian Teori}

Rumah Limas merupakan rumah dengan sistem panggung dengan atap berbentuk piramida terpenggal seperti pada rumah joglo. Rumah ini merupakan rumah tradisional yang banyak ditemukan di Sumatera Selatan. Rumah Limas telah menjadi simbol budaya masyarakat Palembang dan Sumatera Selatan secara umum. Rumah Limas dianggap istimewa karena selain memiliki nilai-nilai filosofis, perencanaannya membutuhkan jangka waktu yang panjang. Dibutuhkan perencanaan yang sangat matang mulai tahap pra-perancangan sampai ke tahap pembangunan. Dibutuhkan beberapa upacara adat untuk meresmikan suatu perancangan Rumah Limas (Pratama, 2019).

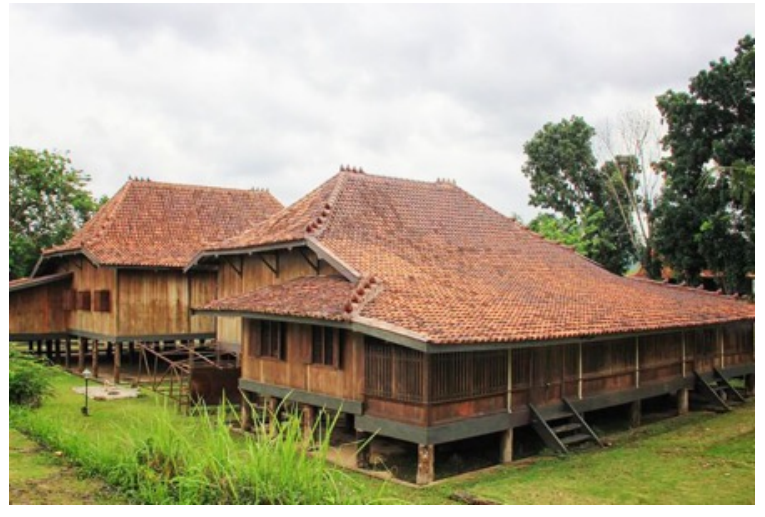

Gambar 1. Rumah Limas Sumatera Selatan

Sumber: Indonesia.go.id 2019

Nilai filosofis yang terkandung pada Rumah Limas yang paling terasa adalah nilai-nilai Islam karena masyarakat Palembang dikenal dengan masyarakat yang relijius. Walaupun demikian, bentuk Rumah Limas juga mengadposi berbagai adat dari suku-suku yang ada di Palembang. Selain itu, bentuk Rumah Limas juga dipengaruhi oleh bentuk arsitektur peninggalan kejayaan kerajaan Hindu-Budha sehingga Rumah Limas dapat dikatakan merupakan rumah hasi akulturasi budaya (Pratama, 2019).

Selain sebagai rumah tinggal, Rumah Limas juga berfungsi sebagai tempat dilakukannya upacara-upacara keagamaan yang dilaksanakan mulai dari pra perancangan, pra pembangunan, pra penempatan rumah sampai ke post pembangunan rumah. Banyak norma-norma yang harus dipatuhi dalam proses pelaksaanan pembangunan rumah Limas mulai dari pembagian ruang, penerapan sistem konstruksi sampai ke pemilihan material bangunan. Hal ini dilakukan demi menjaga nilai-nilai transendental yang ingin tetap dijaga (Pratama, 2019).

Secara prinsip, Rumah Limas memiliki ciri khas yang sangat kuat yaitu pada atap yang memiliki kemiringan sebesar $45^{\circ}$ pada atap utama dan $30^{\circ}$ pada atap teras. Pada atap utama menggunakan material genting berbentuk kelinting dan pada atap teras menggunakan material genting dengan model belah buluh berbentuk bambu terbelah dua yang berfungsi untuk mengaitkan satu sama lain. Pada atap utama terdapat bubungan yang diperkokoh dengan tiga buah tanduk kambing yang terbuat dari beton, tanduk kambing ini juga digunakan di bagian ujung atap (Tondi \& Iryani, 2018).

Pada badan rumah atau selubung bangunan, Rumah Limas menggunakan material papan (dinding papan) yang telah disesuaikan dimensinya dengan elevasi lantai ruang yang berundak-undak. Kemudian, kolom strukutr untuk menopang beban bangunan pada Rumah Limas menggunakan tiang-tiang yang ditanam ke dalam tanah. Tiang-tiang tesebut diberi ukiran dan ornamen sebagai identitas dan ciri khas pemilik rumah.

Pada interior, Rumah Limas terbagi menjadi dua bagian yaitu, induk rumah dan Jogan (teras). Pada induk rumah terdapat beberapa ruang yaitu, ruang penganten, ruang keputren, ruang gegajah dan ruang kepala keluarga yang 
masing-masing memiliki elevasi lantai yang berbeda (berundak) disebut dengan istilah kekijing (Pratama, 2019). Rumah Limas merupakan rumah yang diperuntukkan untuk keluarga besar yang terdiri dari orang tua, anak, menantu dan cucu sehingga luasan rumah sangat besar. Kekijing saat ini banyak difungsikan sebagai pembagi hirarki ruang di mana ruang atau kamar untuk orang tua berada di elevasi yang lebih tinggi (Siswanto, 2009).

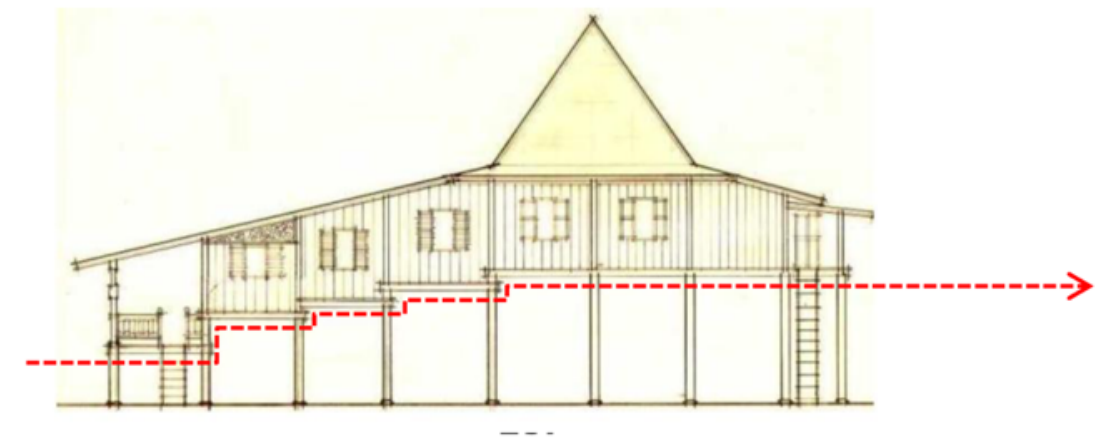

Gambar 2. Penerapan kekijing pada Rumah Limas

Sumber : (Siswanto, 2009)

Fasad yang terbentuk pada Rumah Limas merupakan perpaduan dari bentuk atap yang curam, material kayu yang dominan pada dinding dan ukiran-ukiran sebagai ornamen. Bagian depan Rumah Limas tidak terdapat jendela, namun terdapat dinding berupa kisi-kisi (ruji-ruji) berbahan kayu yang dapat berfungsi sebagai ventilasi. Terdapat ornamen berbentuk trisula atau bunga melati yang terletak pada bagian tengah bubungan atap atau biasa disebut dengan ornamen Simbar (Budiarto, Indriani, \& Ratna, 2017). Fasad pada Rumah Limas dihiasi dengan ukiran pada bagian di atas pintu dengan motif flora dan tulisan arab. Pada dinding terbagi ke dalam dua bagian yaitu, dinding bawah dan dinding garang (tengah sampai atas). Pintu didesain harmoni dengan dinding garang dari segi motif dan materialnya. Terdapat ornamen yang khas pada dinding garang bagian atas yaitu ornamen denga motif pucuk rebung yang digunakan sepanjang lebar fasad (Indriani, Ratna, \& Budiarto, 2019).

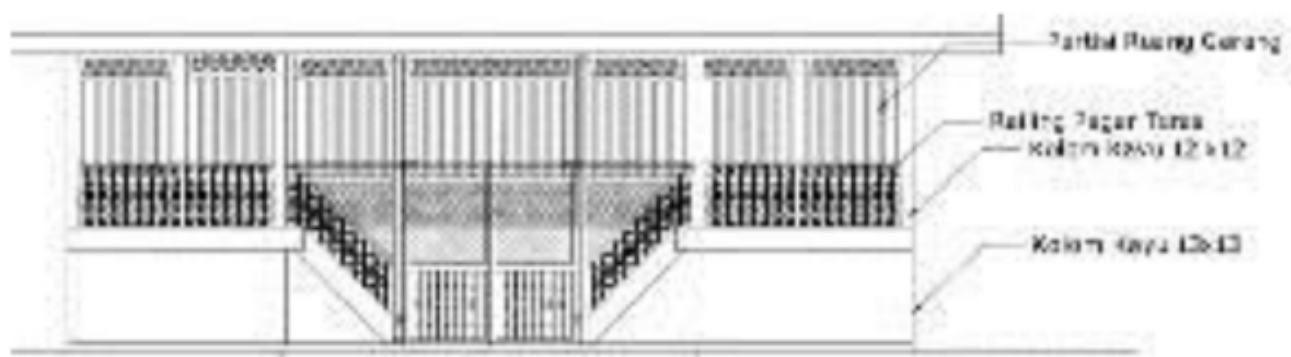

Gambar 3. Fasad Rumah Limas

Sumber: (Budiarto et al., 2017)

Rumah Limas yang merupakan rumah panggung, memiliki dua tangga bada bagian kanan dan kiri bangunan sebagai akses utama untuk mencapai bagian dalam rumah. Tangga ini terbuat dari material papan kayu dan memiliki anak tangga yang berjumlah tujuh buah. Terdapat ornamen pada tangga yang fungsinya sebagai pasak kayu. Ornamen flora juga digunakan sebagai hiasan pada railing tangga yaitu ornamen dengan motif bunga. Terdapat pula ornament berbentuk bintang untuk menutupi bagian pasak pada lantai garang (Indriani et al., 2019). Selain tangga, terdapat pula ornamen flora yang digunakan pada bagian pagar Rumah Limas. Pagar pada Rumah Limas dinamakan Pagar Tenggalong, pagar yang berbentuk kisi-kisi atau disebut juga dengan kerang-kerang dengan ornamen pada bagian luar dan dalamnya.

Sehingga dapat dirumuskan, ciri-ciri arsitektur Rumah Limas adalah seperti pada tabel berikut: 
Table 1. Ciri-ciri Rumah Limas di Sumatera Selatan

\begin{tabular}{|c|c|c|}
\hline $\begin{array}{l}\text { No } \\
1\end{array}$ & $\begin{array}{l}\text { Elemen Arsitektur } \\
\text { Atap }\end{array}$ & $\begin{array}{l}\text { Ciri khas } \\
-\quad \text { Terdapat dua; atap utama dan atap teras } \\
\text { - } \quad \text { Atap utama mempunyai kemiringan } 45^{\circ} \text {, atap teras } 30^{\circ} \\
\text { - } \quad \text { Terdapat pengikat berupa ornament tiga tanduk kambing dari beton pada } \\
\quad \text { bubungan atap dan pada bagian-bagian ujung atap } \\
\text { - } \quad \text { Material penutup atap terbuat dari genting } \\
\text { - } \quad \text { Atap berundak-undak atau disebut juga dengan kekijing }\end{array}$ \\
\hline 2 & Ruang & $\begin{array}{l}\text { - } \quad \text { Terdapat ruang penganten, ruang keputren, ruang gegajah dan ruang } \\
\text { kepala keluarga } \\
\text { - } \quad \text { Elevasi pada tiap ruang berbeda, disebut kekijinng }\end{array}$ \\
\hline 3 & Tiang & $\begin{array}{ll}- & \text { Tiang sebagai penopang utama struktur bangunan Rumah Limas } \\
\text { - } & \text { Tiang tertanam ke dalam tanah }\end{array}$ \\
\hline 4 & Dinding & $\begin{array}{ll}- & \text { Terbuat dari papan kayu } \\
\text { - } & \text { Terdapat dua bagian: Dinding bawah dan dinding garang } \\
\text { - } & \text { Terdapat kisi-kisi atau ruji-ruji sebagai pengganti jendela }\end{array}$ \\
\hline 5 & Ornamen & $\begin{array}{ll}\text { - } & \text { Ornamen taduk kambing pada bubungan } \\
\text { - } & \text { Ornamen berupa ukiran berbentuk flora dan tulisan arab pada dinding } \\
\text { - } & \text { Ornamen berbentuk bintang pada tangga } \\
\text { - } & \text { Ornamen bunga pada railing tangga } \\
\text { - } & \text { Ornamen bermotif pucuk rebung pada bagian atas pintu dan dinding } \\
& \text { garang } \\
\text { - } & \text { Ornamen Simbar pada pecek lawang (bagian atas pintu dan jendela) } \\
\text { - } & \text { Ornamen dengan motif pucuk rebung pada kisi-kisi pagar }\end{array}$ \\
\hline 6 & Jendela & $\begin{array}{ll}\text { - } & \text { Tidak ada jendela di bagian fasad } \\
\text { - } & \text { Pada bagian fasad hanya ada kisi-kisi kayu(ruji-ruji) pada dinding yang } \\
\text { - } & \text { berfungsi seperti jendela untuk memasukkan udara ke dalam bangunan } \\
\text { - } & \text { Ukuran jendela hampir sama dengan pintu }\end{array}$ \\
\hline 7 & Pintu & - $\quad$ Terdapat pintu yang dapat dibuka ke atas (lawang kipas) \\
\hline 8 & Sistem Struktur & $\begin{array}{ll}\text { - } & \text { Menggunakan struktur panggung } \\
\text { - } & \text { Mengandalkan sambungan kayu dan pasak } \\
\end{array}$ \\
\hline 9 & Tangga & $\begin{array}{ll}- & \text { Terdapat di bagian luar sebagai akses utama untuk menuju ruang dalam } \\
\text { - } & \text { Terdapat dua buah, terbentang sejajar pada fasad rumah } \\
\text { - } & \text { Terdapat tujuh buah anak tangga } \\
\text { - } & \text { Terbuat dari material papan kayu } \\
\end{array}$ \\
\hline 10 & Lantai & $\begin{array}{ll} & \text { Terdapat perbedaan elevasi lantai (kekijing) } \\
\text { - } & \text { Terdapat enam perbedaan ketinggian lantai yang berfungsi sebagai } \\
& \text { pembagi hirarki ruang }\end{array}$ \\
\hline 11 & Pagar & - $\quad$ Berupa kisi-kisi dengan ornamen di bagian luar dan dalam \\
\hline
\end{tabular}

\section{Metode}

Metode yang digunakan dalam penelitian ini adalah metode komparatif di mana arsitektur Rumah Limas yang berada di Kabupaten Tanggamus akan dibandingkan dengan Rumah Limas yang berada di daerah asalnya yaitu di Sumatera Selatan

\subsection{Metode Pengumpulan Data}

Terdapat beberapa metode yang dilakukan dalam tahap pengumpulan data untuk mencapai penelitian ini, di antaranya adalah:

1. Studi literatur

Untuk mencari ciri dan karakteristik Rumah Limas di Sumatera Selatan

2. Survei lapangan

Untuk mengobservasi Rumah Limas yang berada di Kecamatan Pulau Panggung

3. Wawancara dengan pemilik rumah dan masyarakat setempat

4. Penggambaran langsung dengan menggunakan sketsa manual meliputi penggambaran denah, tampak, potongan dan perspektif untuk mendapatkan gambaran rinci tentang bentuk rumah limasan 


\subsection{Metode Analisis Data}

Metode analisis data yang dilakukan adalah dengan mengobservasi ciri dan karakteristik bangunan Rumah Limas di Kecamatan Pulau Panggung kemudian mengomparasikannya dengan arsitektur Rumah Limas di daerah asalnya yaitu di Sumatera Selatan untuk mengetahui perubahan yang terjadi pada arsitektur Rumah Limas yang berada di Kecamatan Pulau Panggung.

\section{Hasil dan Pembahasan}

Rumah Limas pada Kecamatan Pulau Panggung, Kabupaten Tanggamus, Lampung, ditemukan ada di empat desa yaitu, Desa Muara Dua, Desa Gunung Meraksa, Desa Tanjung Begelung dan Desa Gunung Megang.

\subsection{Rumah Limas Desa Muara Dua}

Rumah Limas di Desa Muara Dua sekilas terlihat mirip dengan Rumah Limas yang ada di daerah asalnya yaitu di Sumatera Selatan. Hal ini terlihat dari bentuk atap limas, konstruksi panggung, dua buah tangga yang terletak pada bagian dapan bangunan dan pagar yang berbentuk kisi-kisi. Namun, jika dilihat lebih dalam, terdapat banyak perbedaan pada Rumah Limas ini dengan Rumah Limas yang berada di daerah asalnya seperti pada tabel berikut:

Tabel 2. Persamaan dan Perbedaan Rumah Limas di Desa Muara Dua dengan Di Sumatera Selatan

\begin{tabular}{|c|c|c|c|}
\hline No & $\begin{array}{l}\text { Elemen } \\
\text { arsitektur }\end{array}$ & Persamaan & Perbedaan \\
\hline 1 & Atap & $\begin{array}{ll}\text { - } & \text { Berbentuk Limas } \\
\text { - } & \text { Menggunakan material genting } \\
\text { - } & \text { Kemiringan atap curam yaitu } 30^{\circ}\end{array}$ & $\begin{array}{l}\text { - Hanya terdapat satu atap; tidak ada atap teras } \\
\text { - } \\
\text { Tidak terlihat adanya ornamen pada bubungan dan } \\
\text { pada sisi-sisi atap }\end{array}$ \\
\hline 2 & Ruang & $\begin{array}{l}\text { - Berbentuk persegi yang memanjang } \\
\text { ke belakang }\end{array}$ & $\begin{array}{l}\text { - } \quad \text { Tidak terdiri dari ruang pengantin, orang tua dll. } \\
\text { - } \quad \text { Jenis ruang lebih fleksibel dengan kebutuhan ruang } \\
\text { masyarakat modern }\end{array}$ \\
\hline 3 & Tiang & $\begin{array}{ll}\text { - } & \text { Terdapat tiang-tiang sebagai } \\
\text { penyokong struktur bangunan yang } \\
\text { juga menerus sebagai panggung }\end{array}$ & $\begin{array}{l}\text { - Tiang didukung dengan pondasi umpak, sementara } \\
\text { pada daerah asalnya, tiang menerus sampai ke dalam } \\
\text { tanah }\end{array}$ \\
\hline 4 & Dinding & $\begin{array}{l}\text { Terbuat dari papan kayu } \\
\text { - Terdapat dua bagian: Dinding } \\
\text { bawah dan dinding garang }\end{array}$ & $\begin{array}{ll}\text { - } & \text { Tidak ada ruji-ruji }\end{array}$ \\
\hline 5 & Ornamen & $\begin{array}{l}\text { Terdapat ornamen bermotif pucuk } \\
\text { rebung pada bagian dinding bagian } \\
\text { atas, pagar dan railing tangga }\end{array}$ & $\begin{array}{l}\text { - Ragam ornamen yang digunakan sangat sedikit. } \\
\text { Hanya ada ornament bermotif pucuk rebung saja }\end{array}$ \\
\hline 6 & Jendela & - $\quad$ Terbuat dari material kayu & $\begin{array}{ll}- & \text { Terdapat jendela pada bagian fasad } \\
\text { - } & \text { Ukuran jendela sangat berbeda dengan ukuran pintu }\end{array}$ \\
\hline 7 & Pintu & - $\quad$ Terbuat dari material kayu & $\begin{array}{l}\text { - Tidak terlihat adanya pintu yang dapat dibuka ke atas } \\
\text { (lawang kipas) } \\
\text { - } \\
\text { Desain pintu tidak seirama dengan desain dinding }\end{array}$ \\
\hline 8 & $\begin{array}{l}\text { Sistem } \\
\text { Struktur }\end{array}$ & 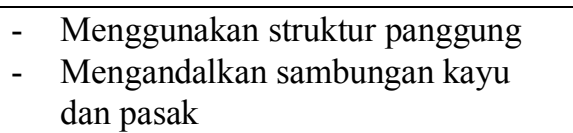 & - Menggunakan pondasi umpak \\
\hline 9 & Tangga & $\begin{array}{ll}\text { - } & \text { Terdapat di bagian luar sebagai } \\
\text { akses utama untuk menuju ruang } \\
\text { dalam } \\
\text { - } & \text { Terdapat dua buah, terbentang } \\
\text { sejajar pada fasad rumah } \\
\text { - } & \text { Terdapat tujuh buah anak tangga } \\
\text { - } & \text { Terbuat dari material papan kayu } \\
\text { - } & \text { Terdapat ornamen flora pada } \\
& \text { railing tangga }\end{array}$ & \\
\hline 10 & Lantai & - & $\begin{array}{ll}- & \text { Tidak terdapat kekijing }\end{array}$ \\
\hline 11 & Pagar & $\begin{array}{ll}- & \text { Berbentuk kisi-kisi } \\
\text { - } & \text { Terdapat ornament pucuk rebung }\end{array}$ & \\
\hline
\end{tabular}




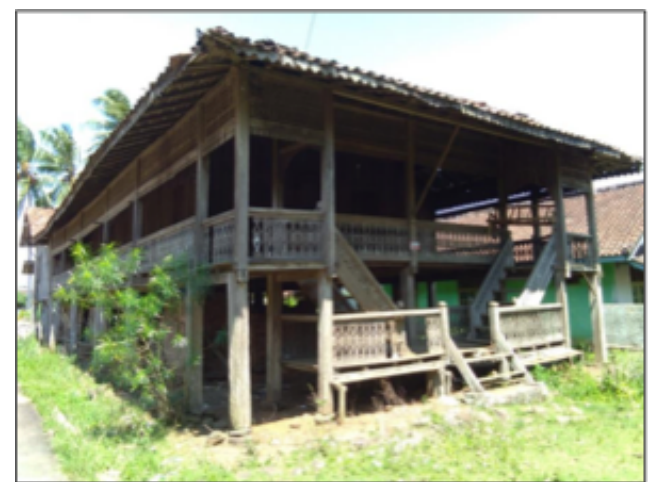

Gambar 4. Rumah Limas di Desa Muara Dua Sumber: Dokumentasi Pribadi
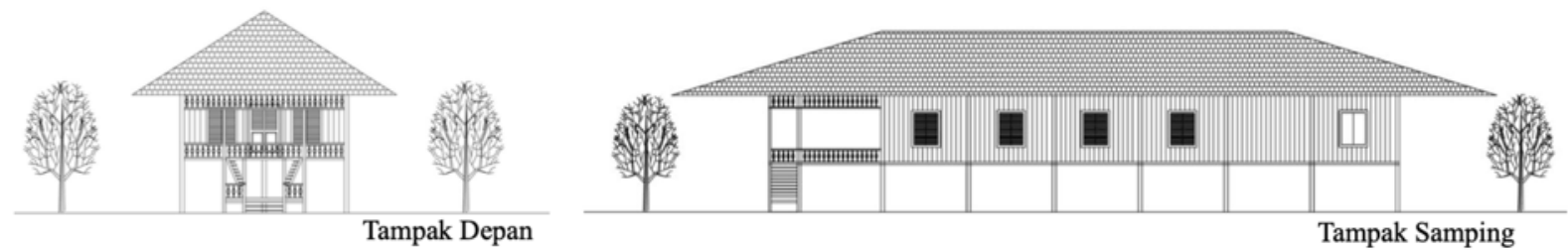

Gambar 5. Tampak Depan dan Tampak Samping Rumah Limas di Desa Muara Dua

Sumber: Dokumentasi Pribadi

Masih banyak terlihat kesamaan antara Rumah Limas di Desa Muara Dua dan di Sumatera Selatan yang terlihat dari desain tangga, atap, pagar, dinding dan ornament. Namun, dapat dilihat bahwa pada bangunan ini sudah tidak ada lagi kekijing yang justru menjadi elemen penting pada Rumah Limas di Sumatera Selatan. Ornamen juga sudah sangat berkurang. Hanya ditemukan di bagian railing tangga dan pagar. Sistem pondasi juga terlihat berbeda. Pada Rumah Limas ini, pondasi yang digunakan adalah pondasi umpak, sementara pada Rumah Limas di Sumatera Selatan, tiang juga berfungsi sebagai pondasi sehingga tiang ditanam sampai ke dalam tanah. Hal ini disebabkan oleh perbedaan jenis tanah antara tanah di Provinsi Lampung yang cenderung kering sementara tanah di Sumatera Selatan cenderung basah atau rawa.

\subsection{Rumah Limas Desa Gunung Meraksa}

Rumah Limas di Desa Gunung Meraksa tidak terlau terlihat mirip dengan Rumah Limas yang ada di daerah asalnya. Ketidak-hadiran area kolong pada rumah ini, membuat Rumah Limas ini tampak sangat berbeda. Area kolong pada rumah ini difugsikan menjadi ruang yang tertutup sehingga kesan rumah panggung menjadi hilang. Persamaannya hanya tinggal di bentuk atap limas dengan kemiringan curam, dominasi material kayu, konstruksi panggung dan dominasi material dinding yang menggunakan papan kayu. Selebihnya, terdapat lebih banyak perbedaan daripada persamaan dengan Rumah Limas yang berada di daerah asalnya. Perbedaan tersebut dapat dilihat pada tabel berikut:

Tabel 3. Persamaan dan Perbedaan Rumah Limas di Desa Gunung Meraksa dengan Di Sumatera Selatan

\begin{tabular}{|c|c|c|c|}
\hline No & $\begin{array}{l}\text { Elemen } \\
\text { arsitektur }\end{array}$ & Persamaan & Perbedaan \\
\hline 1 & Atap & $\begin{array}{ll}\text { - } & \text { Berbentuk Limas } \\
\text { - } & \text { Menggunakan material genting } \\
\text { - } & \text { Kemiringan atap curam yaitu } 30^{\circ}\end{array}$ & $\begin{array}{l}\text { - Hanya terdapat satu atap; tidak ada atap } \\
\text { teras } \\
\text { - Tidak terlihat adanya ornamen pada } \\
\text { bubungan dan pada sisi-sisi atap }\end{array}$ \\
\hline 2 & Ruang & $\begin{array}{l}\text { - Berbentuk persegi yang } \\
\text { memanjang ke belakang }\end{array}$ & $\begin{array}{l}\text { - Tidak terdiri dari ruang pengantin, orang } \\
\text { tua dll. } \\
\text { - Jenis ruang lebih fleksibel dengan } \\
\text { kebutuhan ruang masyarakat modern }\end{array}$ \\
\hline
\end{tabular}




\begin{tabular}{|c|c|c|c|}
\hline 3 & Tiang & $\begin{array}{llr}\text { - } & \text { Terdapat tiang-tiang } & \text { sebagai } \\
\text { penyokong } & \text { struktur } & \text { bangunan } \\
\text { yang juga } & \text { menerus } & \text { sebagai } \\
\text { panggung } & & \end{array}$ & $\begin{array}{l}\text { - Tiang didukung dengan pondasi umpak, } \\
\text { sementara pada daerah asalnya, tiang } \\
\text { menerus sampai ke dalam tanah }\end{array}$ \\
\hline 4 & Dinding & - Terbuat dari papan kayu & $\begin{array}{l}\text { - Tidak ada ruji-ruji } \\
\text { - Tidak ada pembagian dinding bawah dan } \\
\text { dinding garang }\end{array}$ \\
\hline 5 & Ornamen & - & $\begin{array}{l}\text { - Hampir tidak ditemukan adanya } \\
\text { ornamen. Ada ornamen pada bagian } \\
\text { yang menempel pada plafon teras namun } \\
\text { berbeda dengan ornament pada Rumah } \\
\text { Limas di Sumatera Selatan }\end{array}$ \\
\hline 6 & Jendela & $\begin{array}{ll}\text { - } & \text { Tidak ada jendela pada bagian } \\
& \text { fasad } \\
\text { - } & \text { Jendela terdapat di bagian } \\
& \text { samping bangunan } \\
\text { - } & \text { Terbuat dari material kayu } \\
\end{array}$ & $\begin{array}{l}\text { - Ukuran jendela sangat berbeda dengan } \\
\text { ukuran pintu }\end{array}$ \\
\hline 7 & Pintu & - Terbuat dari material kayu & $\begin{array}{l}\text { - Tidak terlihat adanya pintu yang dapat } \\
\text { dibuka ke atas (lawang kipas) } \\
\text { - Desain pintu tidak seirama dengan } \\
\text { desain dinding bahkan pada pintu utama } \\
\text { desainnya sangat kontras dengan } \\
\text { dinding }\end{array}$ \\
\hline 8 & Sistem Struktur & $\begin{array}{l}\text { - Menggunakan struktur panggung } \\
\text { - Mengandalkan sambungan kayu } \\
\text { dan pasak }\end{array}$ & $\begin{array}{l}\text { - Menggunakan pondasi umpak } \\
\text { - Bagian kolong panggung dijadikan ruang }\end{array}$ \\
\hline 9 & Tangga & $\begin{array}{l}\text { Terdapat di bagian luar sebagai } \\
\text { akses utama untuk menuju ruang } \\
\text { dalam }\end{array}$ & $\begin{array}{l}\text { - Terbuat dari bata } \\
\text { - Hanya ada satu tangga } \\
\text { - Hanya ada empat buah anak tangga } \\
\text { - Posisi di samping bangunan bukan di } \\
\text { depan bangunan } \\
\text { - Tidak ada railing tangga }\end{array}$ \\
\hline 10 & Lantai & & - Tidak terdapat kekijing \\
\hline 11 & Pagar & - $\quad$ Berbentuk kisi-kisi & - Tidak ada ornamen \\
\hline
\end{tabular}

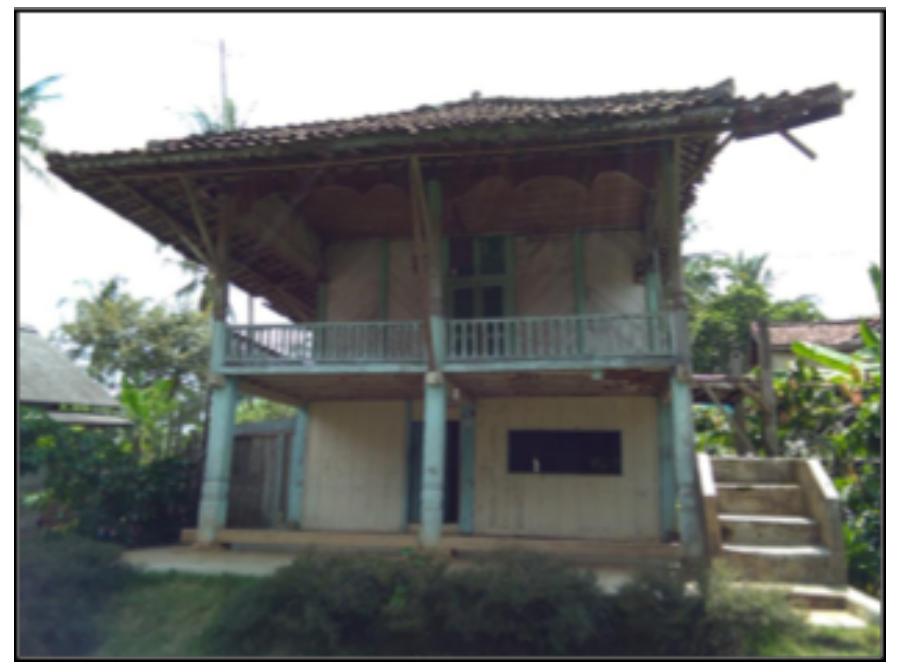

Gambar 6. Rumah Limas di Desa Gunung Meraksa Sumber: Dokumentasi Pribadi 

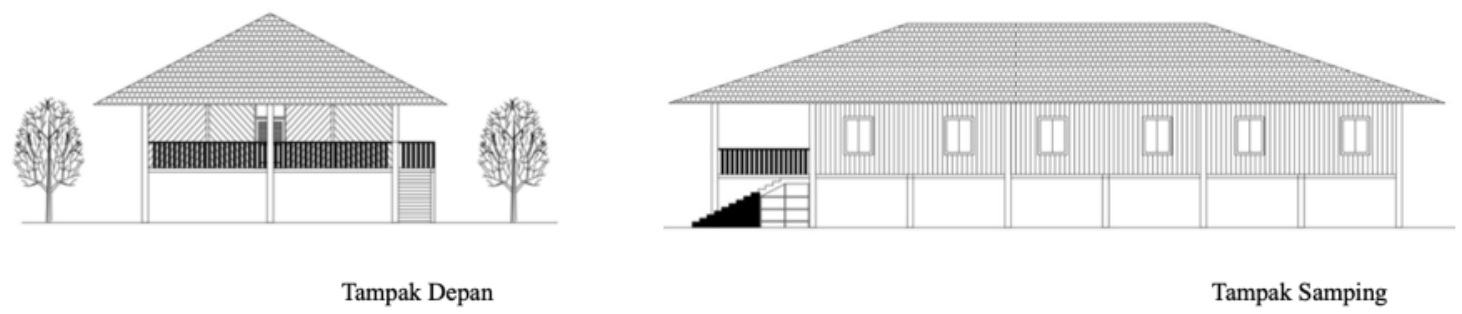

Gambar 7. Tampak Depan dan Tampak Samping Rumah Limas di Desa Gunung Meraksa Sumber: Dokumentasi Pribadi

Posisi tangga yang berada di samping bangunan membuat Rumah Limas yang berada di Desa Gunung Meraksa ini terlihat sangat berbeda dengan Rumah Limas di Sumatera Selatan. Tidak adanya railing tangga dan material tangga yang tidak terbuat dari kayu juga membuat rumah ini berbeda dengan Rumah Limas di tempat asalnya. Ornamentasi tidak ditemukan pada rumah ini baik ornament pada dinding, railing atap dan bagian lain. Rumah ini juga tidak menggunakan sistem kekijing untuk membagi hirarki ruang

\subsection{Rumah Limas Desa Tanjung Begelung}

Rumah Limas di Desa Tanjung Begelung sekilas mirip dengan Rumah Limas yang berada di Desa Gunung Meraksa. Bentuk Rumah Limas di Desa ini sudah tidak terlalu mirip dengan Rumah Limas yang ada di Sumatera Selatan. Sama seperti Rumah Limas di Desa Gunung Meraksa, bagian kolong pada rumah ini sudah ditutup dan difungsikan menjadi ruang permanen. Sehingga kesan rumah panggung menjadi berkurang.

Pada tabel berikut ini dapat dilihat persamaan dan perbedaan pada Rumah Limas di Desa Tanjung Begelung dan Rumah Limas di Sumatera Selatan:

Tabel 4. Persamaan dan Perbedaan Rumah Limas di Desa Tanjung Begelung dengan Di Sumatera Selatan

\begin{tabular}{|c|c|c|c|}
\hline No & $\begin{array}{l}\text { Elemen } \\
\text { arsitektur }\end{array}$ & Persamaan & Perbedaan \\
\hline 1 & Atap & $\begin{array}{l}\text { - Berbentuk Limas } \\
\text { - Menggunakan material genting } \\
\text { - Kemiringan atap curam yaitu } 30^{\circ}\end{array}$ & $\begin{array}{l}\text { - Hanya terdapat satu atap; tidak ada atap } \\
\text { teras } \\
\text { - Tidak terlihat adanya ornamen pada } \\
\text { bubungan dan pada sisi-sisi atap }\end{array}$ \\
\hline 2 & Ruang & $\begin{array}{l}\text { - Berbentuk persegi } \\
\text { memanjang ke belakang }\end{array}$ & $\begin{array}{l}\text { - Tidak terdiri dari ruang pengantin, orang } \\
\text { tua dll. } \\
\text { - Jenis ruang lebih fleksibel dengan } \\
\text { kebutuhan ruang masyarakat modern }\end{array}$ \\
\hline 3 & Tiang & 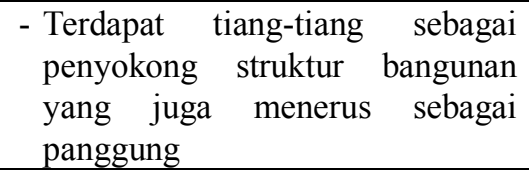 & $\begin{array}{l}\text { - Tiang didukung dengan pondasi umpak, } \\
\text { sementara pada daerah asalnya, tiang } \\
\text { menerus sampai ke dalam tanah }\end{array}$ \\
\hline 4 & Dinding & - Terbuat dari papan kayu & $\begin{array}{l}\text { - Tidak ada ruji-ruji } \\
\text { - Tidak ada pembagian dinding bawah dan } \\
\text { dinding garang }\end{array}$ \\
\hline 5 & Ornamen & - & - Tidak ditemukan adanya ornamen \\
\hline 6 & Jendela & $\begin{array}{l}\text { - Tidak ada jendela pada bagian } \\
\text { fasad } \\
\text { - Jendela terdapat di bagian } \\
\text { samping bangunan } \\
\text { - Terbuat dari material kayu }\end{array}$ & $\begin{array}{l}\text { - Ukuran jendela sangat berbeda dengan } \\
\text { ukuran pintu }\end{array}$ \\
\hline 7 & Pintu & - Terbuat dari material kayu & $\begin{array}{l}\text { - Tidak terlihat adanya pintu yang dapat } \\
\text { dibuka ke atas (102awing kipas) } \\
\text { - Desain pintu tidak seirama dengan } \\
\text { desain dinding bahkan pada pintu utama } \\
\text { desainnya sangat kontras dengan } \\
\text { dinding }\end{array}$ \\
\hline
\end{tabular}




\begin{tabular}{|c|c|c|c|}
\hline 8 & Sistem Struktur & $\begin{array}{l}\text { - Menggunakan struktur panggung } \\
\text { - Mengandalkan sambungan kayu } \\
\text { dan pasak }\end{array}$ & $\begin{array}{l}\text { - Menggunakan pondasi umpak } \\
\text { - Bagian kolong panggung dijadikan ruang }\end{array}$ \\
\hline 9 & Tangga & $\begin{array}{l}\text { - Terdapat di bagian luar sebagai } \\
\text { akses utama untuk menuju ruang } \\
\text { dalam }\end{array}$ & $\begin{array}{l}\text { - Terbuat dari bata } \\
\text { - Hanya ada satu tangga } \\
\text { - Hanya ada empat buah anak tangga } \\
\text { - Posisi di samping bangunan bukan di } \\
\text { depan bangunan } \\
\text { - Tidak ada railing tangga }\end{array}$ \\
\hline 10 & Lantai & & - Tidak terdapat kekijing \\
\hline 11 & Pagar & & $\begin{array}{l}\text { - Tertutup penuh menggunakan material } \\
\text { papan kayu } \\
\text { - Tidak berbentuk kisi-kisi } \\
\text { - Tidak ditemukan ornamen }\end{array}$ \\
\hline
\end{tabular}

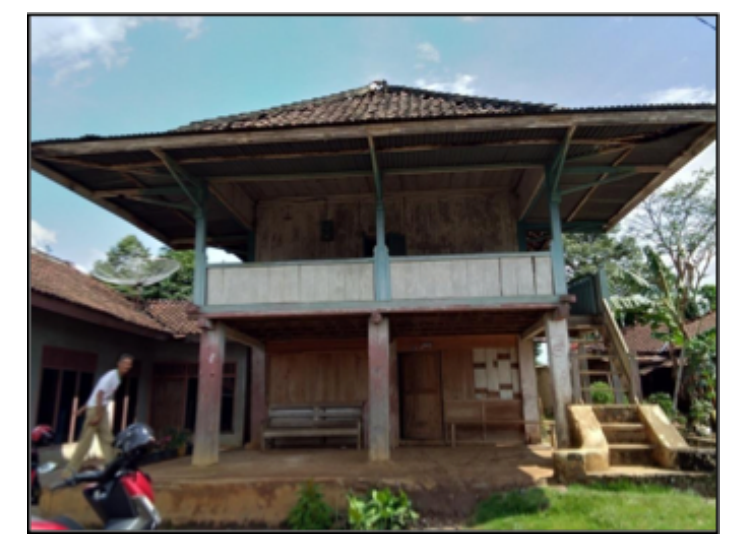

Gambar 8. Rumah Limas di Desa Tanjung Begelung Sumber: Dokumentasi Pribadi
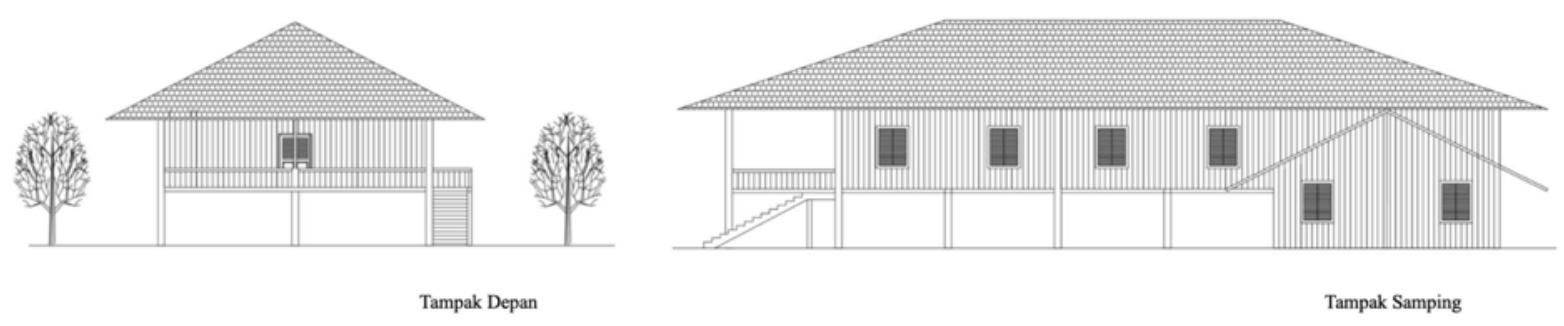

Gambar 9. Tampak Depan dan Tampak Samping Rumah Limas di Desa Tanjung Begelung Sumber: Dokumentasi Pribadi

Posisi tangga yang berada di samping bangunan dan area kolong yang dijadikan ruang tertutup membuat Rumah Limas yang berada di Desa Tanjung Begelung ini terlihat sangat berbeda dengan Rumah Limas di tempat asalnya. Pagar yang digunakan juga tidak menggunakan kisi-kisi melainkan papan yang tertutup rapat menutupi seluruh area pagar juga terlihat sangat kontras dengan desain pagar pada Rumah Limas di Sumatera Selatan. Sistem perbedaan ketinggian lantai sebagai pembagi hirarki ruang atau yang disebut dengan kekijing juga tidak diaplikasikan pada rumah ini. Ornamentasi pada Rumah Limas ini juga sangat minim. Tidak ada ornamen tanduk kambing yang menghiasi area bubungan atap atau ornament flora yang menghiasi dinding dan pagar.

\subsection{Rumah Limas Desa Gunung Megang}

Rumah Limas di Desa Gunung Megang sudah jauh lebih sederhana dari segi bentuk. Ornamentasi juga tidak lagi banyak terlihat sehingga bentuk Rumah Limas pada desa ini sudah jauh sekali berbeda dengan Rumah Limas di Sumatera Selatan. Konstruksi panggung yang rendah serta minimnya ciri khas berupa kisi-kisi pada railing tangga, 
dinding dan pagar membuat Rumah Limas di Desa Gunung Megang terasa seperti memiliki ciri khas yang baru dan tidak bergantung pada prinsip-prinsip desain Rumah Limas di daerah asalnya.

Pada tabel berikut ini dapat dilihat persamaan dan perbedaan pada Rumah Limas di Desa Gunung Megang dan Rumah Limas di Sumatera Selatan:

Tabel 5. Persamaan dan Perbedaan Rumah Limas di Desa Tanjung Begelung dengan Di Sumatera Selatan

\begin{tabular}{|c|c|c|c|}
\hline No & $\begin{array}{l}\text { Elemen } \\
\text { arsitektur }\end{array}$ & Persamaan & Perbedaan \\
\hline 1 & Atap & $\begin{array}{l}\text { - Berbentuk Limas } \\
\text { - Menggunakan material genting } \\
\text { - Kemiringan atap curam yaitu } 30^{\circ}\end{array}$ & $\begin{array}{l}\text { - Hanya terdapat satu atap; tidak ada atap } \\
\text { teras } \\
\text { - Tidak terlihat adanya ornamen pada } \\
\text { bubungan dan pada sisi-sisi atap }\end{array}$ \\
\hline 2 & Ruang & $\begin{array}{l}\text { - Berbentuk persegi yang memanjang ke } \\
\text { belakang }\end{array}$ & $\begin{array}{l}\text { - Tidak terdiri dari ruang pengantin, orang } \\
\text { tua dll. } \\
\text { - Jenis ruang lebih fleksibel dengan } \\
\text { kebutuhan ruang masyarakat modern }\end{array}$ \\
\hline 3 & Tiang & $\begin{array}{l}\text { - Terdapat tiang-tiang sebagai penyokong } \\
\text { struktur bangunan yang juga menerus } \\
\text { sebagai panggung }\end{array}$ & $\begin{array}{l}\text { Tiang didukung dengan pondasi umpak, } \\
\text { sementara pada daerah asalnya, tiang } \\
\text { menerus sampai ke dalam tanah }\end{array}$ \\
\hline 4 & Dinding & - Terbuat dari papan kayu & $\begin{array}{ll} & \text { Tidak ada ruji-ruji } \\
\text { - } & \text { Tidak ada pembagian dinding bawah dan } \\
\text { dinding garang }\end{array}$ \\
\hline 5 & Ornamen & - & - Tidak ditemukan adanya ornamen \\
\hline 6 & Jendela & - Terbuat dari material kayu & $\begin{array}{l}\text { - } \text { Terdapat jendela di bagian fasad } \\
\text { - } \quad \text { Ukuran jendela sangat berbeda dengan } \\
\text { ukuran pintu }\end{array}$ \\
\hline 7 & Pintu & - Terbuat dari material kayu & $\begin{array}{l}\text { Tidak terlihat adanya pintu yang dapat } \\
\text { dibuka ke atas (lawang kipas) } \\
\text { - Desain pintu tidak seirama dengan } \\
\text { desain dinding bahkan pada pintu utama } \\
\text { desainnya sangat kontras dengan } \\
\text { dinding }\end{array}$ \\
\hline 8 & Sistem Struktur & $\begin{array}{l}\text { - Menggunakan struktur panggung } \\
\text { - Mengandalkan sambungan kayu dan } \\
\text { pasak } \\
\text { - Menggunakan konstruksi panggung } \\
\end{array}$ & - Menggunakan pondasi umpak \\
\hline 9 & Tangga & $\begin{array}{l}\text { - Terdapat di bagian luar sebagai akses } \\
\text { utama untuk menuju ruang dalam } \\
\text { - Terbuat dari material kayu } \\
\text { - Posisi di bagian depan bangunan }\end{array}$ & $\begin{array}{ll} & \text { Terbuat dari bata } \\
\text { - } & \text { Hanya ada satu tangga } \\
\text { - } & \text { Hanya ada empat buah anak tangga } \\
\text { - } & \text { Tidak ada railing tangga dan ornamen }\end{array}$ \\
\hline 10 & Lantai & - Luas lantai lebih kecil & - $\quad$ Tidak terdapat kekijing \\
\hline 11 & Pagar & & $\begin{array}{ll}\text { - } & \text { Tertutup penuh menggunakan material } \\
\text { papan kayu } \\
\text { - } \\
\text { - } & \text { Tidak berbentuk kisi-kisi } \\
& \text { Tidemukan ornamen }\end{array}$ \\
\hline
\end{tabular}




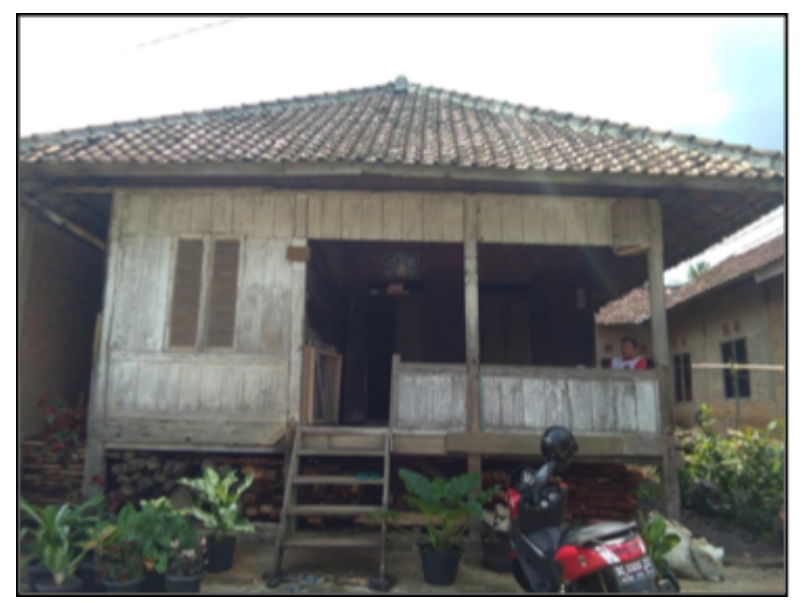

Gambar 10. Rumah Limas di Desa Gunung Megang

Sumber: Dokumentasi Pribadi

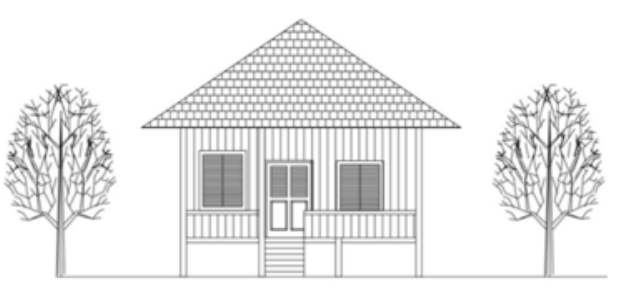

Tampak Depan

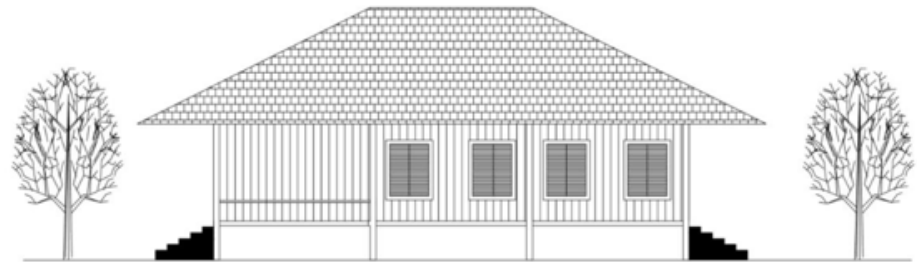

Tampak Samping

Gambar 11. Tampak Depan dan Tampak Samping Rumah Limas di Desa Gunung Megang Sumber: Dokumentasi Pribadi

Dibandingkan dengan tiga desa sebelumnya, Rumah Limas di Desa Gunung Megang merupakan Rumah Limas dengan ciri khas yang jauh berbeda dengan ciri Rumah Limas yang berada di daerah asalnya yaitu Sumatera Selatan. Posisi tangga tunggal yang berada di depan bangunan, jendela yang terdapat di muka bangunan, serta ketinggian panggung yang sangat rendah menjadikan Rumah Limas ini sangat kontras dengan Rumah Limas Sumatera Selatan. Selain itu, rumah ini juga tidak mengaplikasikan kekijing dan juga tidak membagi dindingnya menjadi dua bagian.

\section{Kesimpulan}

Rumah Limas pada Kecamatan Pulau Panggung, Kabupaten Tanggamus, Provinsi Lampung sudah banyak mengalami perubahan meskipun masih ada upaya untuk mempertahankan beberapa prinsip yang mendasar seperti penggunaan konstruksi panggung dan atap berbentuk limas. Rumah Limas yang cirinya masih sangat mirip dengan Rumah Limas di Sumatera Selatan adalah Rumah Limas di Desa Muara Dua. Sementara, Rumah Limas yang sudah mengalami banyak perubahan adalah di Desa Gunung Megang.

Elemen arsitektur yang sudah banyak tidak digunakan pada Rumah Limas di Provinsi Lampung adalah kekijing yaitu perbedaan ketinggian lantai untuk membagi hirarki ruang. Pintu lawang kipas, ornament pada bubungan atap dan pada sisi-sisi atap, serta dinding kisi-kisi yang menjadi ciri khas fasad Rumah Limas Sumatera Selatan juga sudah jarang ditemukan.

Hal ini mengindikasikan bahwa letak geografis dan akulturasi budaya memengaruhi perubahan pada arsitektur Rumah Limas meskipun suku yang membangun Rumah Limas tersebut adalah suku yang berasal dari Sumatera Selatan yaitu Suku Semende. Terdapat pula faktor lain yang turut memengaruhi sulitnya mengadaptasikan Rumah Limas agar bisa mirip dengan Rumah Limas di daerah asalnya yaitu faktor mahalnya membangun satu unit Rumah Limas, kurangnya dukungan pemerintah dan juga perkembangan jaman yang menawarkan variasi material bangunan rumah yang lebih murah dan mudah didapatkan. 


\section{Daftar Pustaka}

Budiarto, A., Indriani, I., \& Ratna, A. M. (2017). Tipologi Fasad Arsitektur Melayu dengan Fasad Arsitektur Tradisional Pelembang, I017-1024. https://doi.org/10.32315/ti.6.i017

Indriani, I., Ratna, A. M., \& Budiarto, A. (2019). Pengaruh Gaya Arsitektur Melayu pada Elemen Tampak Bangunan Rumah Limas Palembang Pendahuluan Kajian Teori Metode, 17, 33-47.

NN, T. (n.d.). Seni Budaya Semende, Lestarikan Kekayaan Budaya Lokal di Lampung. Retrieved July 5, 2020, from https://nusantaranews.co/seni-budaya-semende-lestarikan-kekayaan-budaya-lokal-di-lampung/

Pemerintah Provinsi Lampung. (n.d.). Sejarah Lampung. Retrieved July 5, 2020, from https://www.lampungprov.go.id/pages/sejarah-lampung

Pratama, Y. (2019). Rumah limas : Refleksi Sejarah Akulturasi Kebudayaan Masyarakat Sumatera Selatan. JHCJ : Jambura History and Culture Journal, 1(1). Retrieved from https://ejurnal.ung.ac.id/index.php/jhcj/article/download/2529/1516

Siswanto, A. (2009). Kearifan Lokal Arsitektur Sumatera Selatan Bagi Pembangunan Lingkungan Binaan. Local Wisdom, I(1), 38-45. Retrieved from http://localwisdom.ucoz.com/_ld/0/5_1ed_5_JLWOL_ari.pdf

Tondi, M. L., \& Iryani, S. Y. (2018). Nilai Dan Makna Kearifan Lokal Rumah Tradisional Limas Palembang Sebagai Kriteria Masyarakat Melayu. Langkau Betang: Jurnal Arsitektur, 5(1), 15. https://doi.org/10.26418/lantang.v5i1.25383

Warganegara, A. (n.d.). Sejarah Pembentukan Provinsi Lampung 1945-1965 (4). Retrieved July 11, 2020, from https://www.teraslampung.com/sejarah-kolonisas-di-lampung-mereka-datang-dari-bagelen/

Wijaya, T. (n.d.). Anak Gunung Yang Mencintai Laut, Siapa Dia. Retrieved July 11, 2020, from https://www.mongabay.co.id/2016/12/05/anak-gunung-yang-mencintai-laut-siapa-dia/ 